\title{
PENGARUH PENGGUNAAN MODUL KONTEKSTUAL BERBASIS MULTIREPRESENTASI PADA MATERI GRAVITASI NEWTON TERHADAP KEMAMPUAN BERPIKIR KRITIS SISWA
}

\author{
Tiara Shavira, Chandra Ertikanto, Agus Suyatna \\ Program Studi Pendidikan Fisika, Universitas Lampung \\ Email: tiarashavira068@gmail.com
}

Diterima: 9 Juni 2018. Disetujui: 4 Juli 2018.

\begin{abstract}
Abstrak
Penelitian ini bertujuan untuk mengetahui pengaruh penggunaan modul kontekstual berbasis multirepresentasi pada materi Hukum Newton tentang gravitasi terhadap kemampuan berpikir kritis siswa. Sampel penelitian ini adalah siswa kelas X IPA 1 dan X IPA 2 SMA Muhammadiyah 1 Kotaagung. Penelitian ini dilakukan menggunakan quasi eksperimental dengan tipe Pretest-Posttest Control Group Design. Data diuji dengan analisis N-gain, uji normalitas, uji homogenitas, uji paired sample t test, dan Analysis Of Covariance. Berdasarkan hasil analisis data diketahui bahwa kemampuan berpikir kritis pada kelas eskperimen sebesar 0,71 dengan kategori tinggi, sedangkan kelas kontrol dengan kategori sedang sebesar 0,60. Penggunaan modul pembelajaran kontekstual berbasis multirepresentasi pada materi Hukum Newton gravitasi mampu meningkatkan kemampuan berpikir kritis siswa di SMA Muhammadiyah 1 Kotaagung.

Kata Kunci: kemampuan berpikir kritis, modul kontekstual, multirepresentasi.
\end{abstract}

\begin{abstract}
This study aims to determine the effect of using multirepresentation contextual module on the critical thinking ability. The sample of this research is the students of class XIPA 1 and X IPA 2 Muhammadiyah 1 Kota Agung Senior High School. This research was conducted using quasi experimental with Pretest-Posttest Control Group Design type. Data were tested with $\mathrm{N}$-gain analysis, normality test, homogeneity test, paired sample $t$ test, and Analysis Of Covariance. Based on data analyze, the $N$-gain value, the average $\mathrm{N}$-gain critical thinking ability in the experimental class is 0.71 with the high category, while the control class with the medium category is 0.60. The use of Multirepresentation Contextual Module on Newton's Law Subject Gravity able to improve students' critical thinking ability in Muhammadiyah 1 Kota Agung Senior High School.

Keywords: critical learning ability, contextual learning module, multirepresentation.
\end{abstract}

\section{PENDAHULUAN}

Pendidikan di Indonesia telah menggunakan kurikulum baru yang

$$
\text { telah serempak dilaksanakan }
$$

$$
\text { diseluruh Indonesia pada tahun } 2017
$$

yaitu kurikulum 2013 revisi. 
Shavira., Ertikanto., Suyatna. - Pengaruh Penggunaan Modul Kontekstual...

Kurikulum inilah yang membedakan dengan kurikulum sebelumnya bahwasanya terdapat perubahan pembelajaran dari pembelajaran konven-sional menuju pembelajaran dengan pendekatan kontekstual. Esensi pendekatan kontekstual adalah membantu siswa mampu merelevansi teori belajar dengan kehidupan nyata (Pohan, Atmazaki, \& Agustina, 2014). Melalui kurikulum 2013 revisi diharapkan dapat mencapai standar kompetensi pembelajaran fisika yang tertuang dalam Permendikbud nomor 64 tahun 2013 yaitu mengembangkan keterampilan berpikir kritis melalui pembelajaran fisika, ini menunjukkan bahwa proses maupun asesmen pembelajaran fisika harus berorientasi untuk mengembangkan keterampilan berpikir kritis siswa.

Kendala yang dihadapi oleh peserta didik, guru maupun sekolah salah satunya adalah terbatasnya keter-sediaan media pelajaran yang mengacu pada kurikulum 2013, khususnya buku fisika SMA. Salah satu bahan ajar yang bisa dikembangkan yaitu modul. Modul merupakan salah satu bentuk bahan ajar cetak yang disajikan secara sistematis, sehingga penggunanya dapat belajar dengan atau tanpa guru, sebagaimana diketahui bahwa fisika merupakan disiplin ilmu yang mempelajari gejala alam dan menerangkan bagaimana gejala tersebut terjadi. Modul semestinya dibuat dan memiliki kelebihan khususnya pada pembelajaran fisika karena merupakan mata pelajaran yang tidak hanya berisi teori dan rumus untuk dihafal, tetapi fisika memerlukan pengertian dan pemahaman konsep yang dititik beratkan pada proses terbentuknya pengetahuan melalui suatu penemuan maupun penyajian data. Permasalahan yang sering terjadi di dalam pembelajaran fisika adalah umumnya siswa cenderung pasif sehingga membuat siswa kurang mengembangkan keterampilan berpikirnya (Prasetyo, Fauzi, \& Wiyono, 2015).

Pelaksanaan proses pembelajaran, diketahui bahwa bahan ajar yang digunakan oleh siswa hanya berupa Lembar Kerja Siswa (LKS). Siswa tidak diberikan bahan ajar lain seperti modul, buku paket, brosur, handout, dan leaflet sebagai sumber belajar 
Shavira., Ertikanto., Suyatna. - Pengaruh Penggunaan Modul Kontekstual...

dalam kegiatan belajar siswa. LKS juga belum bisa mengembangkan diri siswa dalam mengembangkan pengetahuan dan keterampilan berpikir sehingga siswa masih kesulitan dalam menyelesaikan persoalan yang diajukan kepadanya. Siswa juga masih ketergantungan terhadap siswa yang lain dalam kegiatan belajar. Selain itu, terdapat beberapa kelemahan yang dimiliki oleh LKS, yaitu LKS kurang menarik karena dicetak menggunakan kertas buram dan hanya terdapat warna pada sampul, materi yang disajikan masih terlalu banyak dengan penjelasan yang kurang terarah pada topik bahasan, bahasa yang digunakan membuat siswa sulit memahaminya, terdapat banyak soal baik pilihan ganda dan uraian yang hanya melatihkan segi kognitif siswa, sehingga keterampilan berpikir siswa belum dapat terpenuhi, dan tidak adanya peta konsep.

Hampir semua guru di sekolah menggunakan bahan ajar bukan berupa modul, bahan ajar pasti multirepresentasi, tetapi tidak sedikit siswa dengan mudah memahami dan memecahkan masalah dengan menghubungkan keterkatikan gambar, grafik, diagram, verbal, dan rumus pada suatu materi. Banyak bahan ajar menyediakan materi pembelajaran disusun secara sistematis tetapi hanya mengaitkan gambar dengan verbal serta rumus jadi sehingga siswa kerap mengalami kekeliruan bagaimana keterkaitan rumus dengan materi tersebut, oleh karena itu diperlukan sumber belajar lain yang mampu meningkatkan pemahaman dan kemampuan berpikir siswa dalam mempelajari materi pelajaran. Salah satu sumber belajar tersebut yaitu modul pembelajaran yang mampu memberikan kesempatan kepada siswa dalam mengembangkan pengetahuan dan keterampilan dalam menyerap materi pembelajaran dalam modul.

Multirepresentasi bertujuan memberikan kesempatan baik kepada guru maupun siswa dalam merepresentasikan konsep dalam berbagai cara dan bentuk. Penggunaannya dalam proses pembelajaran ditunjang dengan penggunaan media yang mendukung dan direncanakan dengan baik. Pemanfaatan komputer dan aplikasi phet simulation menjadi 
Shavira., Ertikanto., Suyatna. - Pengaruh Penggunaan Modul Kontekstual...

satu alternatif yang menawarkan Newton tentang gravitasi, 64\% siswa banyak keuntungan dalam menganggap bahwa fisika tidak menerapkan multirepresentasi dalam menarik. Hal itu dikarenakan pembelajaran fisika. Modul kontekstual berbasis multirepresentasi diharapkan siswa dapat lebih menyenangi fisika karena bukan hanya rumus-rumus yang diberikan tetapi juga cara-cara lain untuk memahami suatu konsep.

Bahan ajar yang baik digunakan dalam pembelajaran kontekstual yaitu dengan berbasis multirepresentasi. Representasi membantu siswa dalam pembentukan pengetahuan dan pemecahan masalah (Abdurrahman, et al, 2011). Pembelajaran dengan multirepresentasi diharapkan mampu untuk menjembatani proses pemahaman siswa terhadap konsepkonsep fisika sehingga dapat meningkatkan kemampuan berpikir kritis siswa dan dapat meningkatkan hasil belajar siswa (Khotimah, Nyeneng, \& Sesunan, 2017).

Berdasarkan hasil penelitian yang telah dilakukan oleh Fatmala, Nyeneng dan Suana (2017) yang berjudul pengembangan modul pembelajaran kontekstual berbasis multirepresentasi pada materi hukum kurangnya bahan ajar, yang tersedia hanya berupa buku ajar yang disediakan oleh pihak sekolah, di mana buku tersebut hanya dapat dipinjam pada saat pembelajaran serta isi materi hanya disajikan dalam representasi verbal berupa teori-teori serta matematis berupa rumus-rumus fisika yang sulit dimengerti dan dipahami. Sementara itu, 36\% siswa mengganggap fisika menarik dikarenakan dalam pembelajaran fisika, guru menggunakan media pembelajaran berupa globe, namun karena hal tersebut, siswa tidak pernah melakukan pembelajaran dan praktikum langsung mengenai materi yang diajarkan sehingga siswa sulit menerapkan pengetahuan yang diperoleh di kehidupan sehari-hari.

Pembelajaran fisika tidak semuanya bisa dilaksanakan melalui pelaksanaan percobaan di laboratorium, dalam beberapa materi perhitungan rumus tidak dilakukan secara ideal, misalnya dengan meniadakan pengaruh variabel tertentu, contohnya dalam 
Shavira., Ertikanto., Suyatna. - Pengaruh Penggunaan Modul Kontekstual...

pembelajaran Hukum Newton tentang gravitasi, yaitu perumusan hukum gravitasi newton, medan gravitasi dan potensial gravitasi, pada materi ini meninjau ketinggian, waktu, kecepatan sehingga diperoleh grafik yang bersifat konstan menyerupai grafik linier. Guna memberikan visualisasi yang tepat, dibutuhkan alat bantu untuk mensimulasikannya. Maka pemanfaatan media pembelajaran penting untuk membantu siswa meningkatkan pemahaman, menyajikan data dengan menarik dan terpercaya, memudahkan penafsiran data dan memadatkan informasi. Hal ini sesuai dengan penelitian yang telah dilakukan oleh (Lestari, Achmad, \& Surbakti, 2016) yang menyatakan bahwa multirepresentasi dapat meningkatkan kemampuan berpikir kritis siswa.

Tujuan penelitian ini untuk mendeskripsikan pengaruh penggunaan modul pembelajaran kontekstual berbasis multirepresentasi pada materi hukum Newton gravitasi terhadap kemampuan berpikir kritis siswa di SMA Muhammadiyah 1 Kota Agung.

\section{METODE}

Penelitian ini merupakan studi kuasi eksperimen dengan populasi penelitian yaitu seluruh siswa kelas $\mathrm{X}$ IPA SMA Muhammadiyah 1 Kota Agung pada semester genap tahun ajaran 2017/2018 yang terdiri dari dua kelas.

Sampel penelitian diambil menggunakan teknik purposive sampling karena kelas yang akan digunakan dalam penelitian ini terdistribusi ke dalam kelas heterogen secara akademik. Pada penelitian ini, sampel yang digunakan diambil dari dua kelas X IPA yang ada di SMA Muhammadiyah 1 Kota Agung, kemudian dapat diperoleh 1 kelas kontrol dan 1 kelas eksperimen. Kelas X IPA 1 sebagai kelas eksperimen dan kelas X IPA 2 sebagai kelas kontrol.

Desain penelitian yang digunakan adalah quasi experimental, menggunakan bentuk non-equivalent control grup design. Pada desain ini terdapat pretest sebelum diberi perlakuan dan posttes setelah diberi perlakuan. Kelas kuasi eksperimen diberi perlakuan menggunakan modul pembelajaran kontekstual berbasis 
Shavira., Ertikanto., Suyatna. - Pengaruh Penggunaan Modul Kontekstual...

multirepresentasi, sedangkan kelas subyek dibandingkan. Diagram kontrol menggunakan buku paket rancangan penelitian seperti yang biasa dipakai di sekolah. Hasil ditunjukkan pada gambar 1.

pretest dan posttest pada kedua kelas

$$
\begin{array}{ccc}
\mathrm{O}_{1} & \mathrm{X} & \mathrm{O}_{2} \\
\mathrm{O}_{3} & & \mathrm{O}_{4}
\end{array}
$$

Gambar 1. Pretest-Posttest Control Group Design

Penelitian ini terdapat dua macam variabel yaitu variabel bebas dan variabel terikat. Variabel bebas dalam penelitian ini adalah penggunaan modul pembelajaran kontekstual berbasis multirepresentasi, sedangkan variabel terikatnya adalah kemampuan berpikir kritis siswa.

Instrumen yang digunakan dalam penelitian ini adalah Rencana Pelaksanaan Pembelajaran (RPP) dan lembar soal tes kemampuan berpikir kritis. Sebelum instrument digunakan dalam sampel, instrumen diuji terlebih dahulu dengan uji validitas dan uji reliabilitas. Pengumpulan data pada penelitian ini dilakukan pada saat sebelum dan setelah kegiatan pembelajaran di kelas kontrol dan kelas eksperimen dari kegiatan pretest dan posttest. Data dalam penelitian ini bersifat kuantitatif yaitu data kemampuan berpikir kritis siswa pada ranah kognitif. Uji yang dilakukan terhadap data tersebut yaitu Uji Normalitas, Uji Homogenitas, Uji N-Gain, dan Uji Paired Sample T Test, dan uji Analysis Of Covariance. Data hasil belajar siswa dianalisis menggunakan data N-Gain yang ternormalisasi.

Uji normalitas dilakukan terhadap data pretest dan data posttest hasil belajar siswa, yang telah didapat dari hasil pembelajaran pada kelas kontrol dan kelas eksperimen. Kemudian dilakukan uji homogenitas untuk melihat kedua kelas mempunyai varians yang tidak jauh berbeda (sama). Pada penelitian ini, uji 
Shavira., Ertikanto., Suyatna. - Pengaruh Penggunaan Modul Kontekstual...

normalitas yang digunakan adalah uji Kolmogrov-Smirnov. Data dikatakan memenuhi asumsi normalitas atau terdistribusi normal jika pada Kolmogorov-Smirnov nilai sig. 0.05 sebaliknya data yang nilai sig. 0.05 tidak terdistribusi normal. Untuk melihat uji homogenitas menggunakan uji levene test dengan kriteria uji adalah jika signifikansi $>0,05$ maka kedua data varians adalah homogen.

Setelah dilakukan uji normalitas, selanjutnya dilakukanlah uji Paired Sample $T$ Test. Uji ini dilakukan untuk melihat perbedaan kemampuan berpikir kritis siswa sebelum dan sesudah diberi perlakuan. Analisis tersebut digunakan untuk mengetahui diterima atau tidaknya hipotesis yang telah dibuat. Kriteria pengujiannya yaitu jika probabilitas (Asymp.Sig) 0,05, maka $\mathrm{H}_{\mathrm{o}}$ ditolak dan jika probabilitas (Asymp.Sig) 0,05, maka $\mathrm{H}_{\mathrm{o}}$ diterima.

Langkah selanjutnya yaitu dilakukan uji Analysis of Covariance, untuk mengetahui ada atau tidaknya perbedaan rata-rata antara dua kelompok sampel yang tidak berhubungan. Kriteria pengujiannya yaitu jika probabilitas (Asymp.Sig) 0,05, maka $\mathrm{H}_{0}$ ditolak dan jika probabilitas (Asymp.Sig) 0,05, maka $\mathrm{H}_{0}$ diterima.

\section{HASIL DAN PEMBAHASAN}

\section{Hasil}

Penelitian pembelajaran menggunakan modul pembelajaran kontekstual berbasis multirepresentasi pada materi Hukum Newton tentang gravitasi ini mulai dilaksanakan pada tanggal 1 Maret 2018 di SMA Muhammadiyah 1 Kota Agung. Proses pembelajaran berlangsung selama 3 kali tatap muka dengan alokasi waktu 9 jam pelajaran yang terdiri atas 45 menit pada setiap jam pelajarannya. Hasil yang diperoleh dari penelitian ini berupa data kuantitatif (kemampuan berpikir kritis) yang selanjutnya diolah dengan menggunakan SPSS versi 21.

Pada penelitian ini kelas yang digunakan sebagai kelas eksperimen adalah kelas X IPA 1 di SMA Muhammadiyah 1 Kota Agung. Pelaksanaan pembelajaran pada kelas ini diikuti oleh 32 siswa. Keseluruhan proses pembelajaran sebanyak tiga kali pertemuan. Pembelajaran 
Shavira., Ertikanto., Suyatna. - Pengaruh Penggunaan Modul Kontekstual...

dilaksanakan selama tiga jam memberikan 22 butir pertanyaan esai. pelajaran dengan alokasi waktu 3x 45 Peningkatan kemampuan berpikir jam pelajaran dan sama untuk setiap kritis siswa diperoleh dari skor $N$ pertemuan. Pembelajaran pada kelas gain yang dihitung dari skor pretest eksperimen menggunakan modul kontekstual berbasis multirepresentasi yang telah dibagikan kepada masingmasing siswa.

Penelitian yang digunakan sebagai kelas control adalah kelas X IPA 2 di SMA Muhammadiyah 1 Kota Agung. Pelaksanaan pembelajaran pada kelas ini diikuti oleh 30 siswa. Keseluruhan proses pembelajaran sebanyak tiga kalipertemuan dengan alokasi waktu $3 \times 45$ menit. Pembelajaran pada kelas kontrol menggunakan buku siswayang digunakan di SMA Muhammadiyah 1 Kota Agung. Data dan skor posttest.

Tabel 1 memperlihatkan bahwa perolehan N-Gain kelas eksperimen sebesar 0,71 dengan kategori tinggi dari pada kelas kontrol dengan perolehan N-Gain sebesar 0,60 dengan kategori sedang, sehingga kelas eksperimen yang menggunakan modul kontekstual berbasis multirepresentasi memperoleh peningkatan kemampuan berpikir kritis lebih tinggi dibanding kelas kontrol yang menggunakan bahan ajar yang dipakai di sekolah pada proses pembelajaran.

hasil belajar siswa diperoleh dengan

Tabel 1. Perolehan N-Gain

\begin{tabular}{cccc}
\hline Kelas & Pretest & Posttest & N-gain \\
\hline Eksperimen & 11,86 & 74,22 & 0,71 \\
Kontrol & 13,24 & 65,54 & 0,60 \\
\hline
\end{tabular}

Tabel 2 meperlihatkan bahwa data nilai rata-rata kemampuan berpikir kritis siswa berdistribusi normal dengan nilai Asymp. Sig. (2-tailed) > 0,05 yaitu 0,195 untuk kelas eksperimen dan 0,141 untuk kelas kontrol. Berdasarkan hasil uji terse- but maka diperoleh bahwa data nilai kemampuan berpikir kritis ranah kognitif dari kelas eksperimen dan kelas kontrol berdistribusi normal.

Setelah Uji Normalitas dilakukan uji homogenitas didapatkan nilai Sig pada kelas eksperimen dan kelas 
Shavira., Ertikanto., Suyatna. - Pengaruh Penggunaan Modul Kontekstual...

kontrol yaitu 0,233, karena (varian kelompok kelas eksperimen signifikansi lebih dari 0,05 maka dan kelas kontrol adalah sama).

diperoleh bahwa kedua varian sama

Tabel 2. Uji Normalitas Data Skor $N$-gain

\begin{tabular}{ccc}
\hline No & Kelas & Asymp. Sig (2-tailed) \\
\hline 1 & Eksperimen & 0,195 \\
2 & Kontrol & 0,141 \\
\hline
\end{tabular}

Setelah di dapat nilai uji maka diperoleh bahwa $\mathrm{H}_{0}$ ditolak dan Normalitas dan uji homogenitas $\mathrm{H}_{1}$ diterima, maka hasil pengujian selanjutnya dilakukan uji hipotesis tersebut dapat diperoleh bahwa pertama dimana untuk melakukan uji "terdapat perbedaan yang signifikan hipotesis di terima atau di tolaknya antara rata-rata hasil pretest-postest di hipotesis dilakukan uji Paired Sample kelas eksperimen".

$T$ Test seperti yang terlihat pada tabel

Uji hipotesis kedua dimana untuk 3. melakukan uji hipotesis diterima atau

Tabel 3 memperlihatkan bahwa penggunaan uji paired sample t test memperoleh nilai Asymp. Sig. (2- terlihat pada tabel 4. tailed) sebesar 0,000 kurang dari 0,05 di tolaknya hipotesis dilakukan uji Analysis Of Covariance seperti yang

Tabel 3. Hasil Uji Paired Sample T Test

\begin{tabular}{cccccc}
\hline Data & $\begin{array}{c}\text { Rata-Rata } \\
\text { (Mean) }\end{array}$ & $\begin{array}{c}\text { Perbedaan Rata-Rata } \\
\text { (Mean) }\end{array}$ & $\mathrm{t}_{\text {hitung }}$ & $d f$ & Sig (2-tailed) \\
\hline $\begin{array}{c}\text { Pretest } \\
\text { Posttest }\end{array}$ & 11,86 & 62,34 & 42,225 & 31 & 0,000 \\
\hline
\end{tabular}

Tabel 4. Hasil Uji Analysis Of Covariance N-Gain

\begin{tabular}{ccccc}
\hline Kelas & $\boldsymbol{N}$ & Mean & $\boldsymbol{S . D}$ & $\mathbf{F}$ \\
\hline Eksperimen & 32 & 0,7075 & 0,08857 & \multirow{2}{*}{13,075} \\
Kontrol & 30 & 0,603 & 0,13216 &
\end{tabular}


Shavira., Ertikanto., Suyatna. - Pengaruh Penggunaan Modul Kontekstual...

Tabel 4 memperlihatkan bahwa berpikir kritis siswa meningkat menpenggunaan uji Analysis of jadi 74,22. Terjadi peningkatan rataCovariance memperoleh nilai Asymp. rata kemampuan berpikir kritis siswa Sig. (2-tailed) sebesar 0,000 kurang sebesar 62,36 setelah diterapkan pemdari 0,050 maka diperoleh bahwa $\mathrm{H}_{0}$ ditolak dan $\mathrm{H}_{1}$ diterima, maka hasil pengujian tersebut diperoleh bahwa nilai $\mathrm{F}_{\text {hitung }}$ pada tabel di atas sebesar 13,075 sedangkan $\mathrm{F}_{\text {Tabel }}$ sebesar 4,00. Nilai $F_{\text {hitung }}>F_{\text {tabel }}(13,075>4,00)$.

Gambar 2 menunjukkan, pada kelas eksperimen rata-rata kemampuan berpikir kritis sebelum diterapkan pembelajaran dengan menggunakan modul pembelajaran kontekstual berbasis multirepresentasi hanya sebesar 11,86 , setelah belajaran dengan menggunakan modul pembelajaran kontekstual berbasis multirepresentasi. Hal yang sama terjadi pada kelas kontrol. Hasil penelitian di kelas kontrol, rata-rata kemampuan berpikir kritis siswa sebelum diterapkan pembelajaran hanya sebesar 13,24, setelah diterapkan pembelajaran rata-rata kemampuan berpikir kritis meningkat menjadi 65,65. Terjadi peningkatan rata-rata kemampuan berpikir kritis siswa sebesar 52,30.

diberikan perlakuan kemampuan

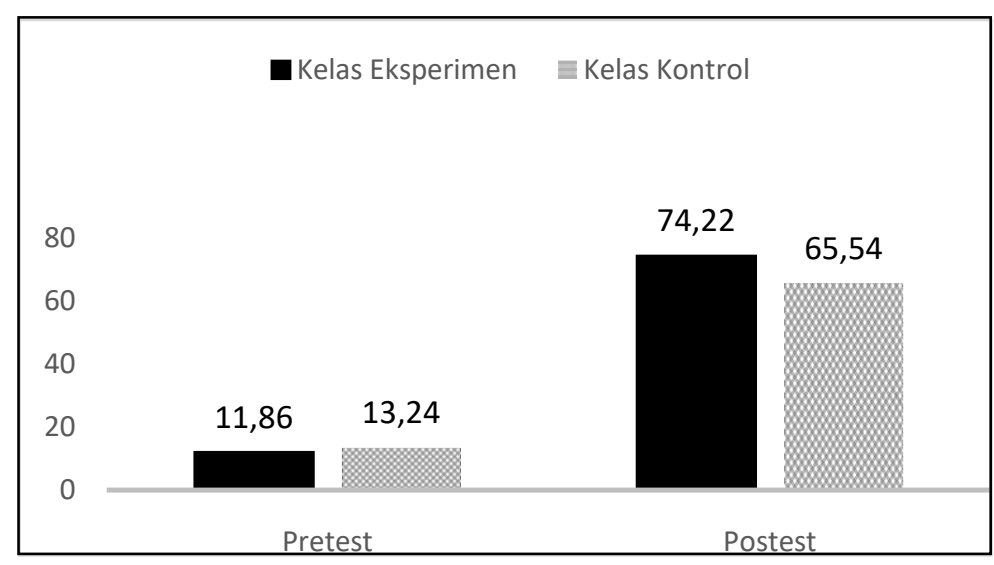

Gambar 2. Grafik Perbandingan Rata-rata Nilai Pretest dan Posttest Kemampuan Berpikir Kritis

Kelas eskperimen memiliki $\mathrm{N}$ - diketahui bahwa pada kelas gain kemampuan berpikir kritis lebih eksperimen siswa yang memperoleh tinggi. Berdasarkan hasil perhitungan kategori tinggi sebanyak 17 siswa 
Shavira., Ertikanto., Suyatna. - Pengaruh Penggunaan Modul Kontekstual...

$(53,13 \%)$, kategori sedang 15 siswa $(46,87 \%)$, dan 0 siswa $(0,00 \%)$ memperoleh kategori rendah. Pada kelas kontrol, siswa yang memperoleh kategori tinggi sebanyak 6 siswa $(20,00 \%)$, ketegori sedang 23 siswa $(76,67 \%)$, dan siswa yang mendapatkan kategori rendah sebanyak 1 siswa $(3,33 \%)$.

\section{Pembahasan}

Perbedaan nilai rata-rata kemampuan berpikir kritis pada masing-masing kelas dapat dilihat dari proses guru dalam menyampaikan materi pembelajaran. Hasil yang diperoleh dari penelitian ini dikarenakan adanya perbedaan perlakuan dari kedua kelas, kelas kontrol pada proses pembelajaran menggunakan bahan ajar yang lazim digunakan di sekolah yaitu LKS.

LKS memiliki kelemahan yaitu kurang menarik karena dicetak menggunakan kertas buram dan hanya terdapat warna pada sampul, materi yang disajikan masih terlalu banyak dengan penjelasan yang kurang terarah pada topik bahasan, bahasa yang digunakan membuat siswa sulit memahaminya, terdapat banyak soal baik pilihan ganda dan uraian yang hanya melatihkan segi kognitif siswa, sehingga keterampilan berpikir siswa belum dapat terpenuhi, dan tidak adanya peta konsep. Proses pemecahan masalah siswa hanya terpaku dengan rumus yang tepat untuk menjawab pertanyaan tanpa mementingkan makna fisis.

Pengaruh positif dari penggunaan multirepresentasi dalam penelitian ini sejalan dengan hasil penelitian dari Irwandani (2014) yang menyatakan bahwa multirepresentasi dapat membantu pembelajaran dalam mempelajari dan membangun konsep dan mengatasi permasalahan. Hasil penelitian dari Asfiah dan Mosik (2013) terkait pengembangan modul IPA yang menyatakan penggunaan modul mampu membantu hasil belajar siswa menjadi lebih baik.

Hasil positif ini juga sesuai dengan hasil penelitian dari Fatmala, et al. (2017) yang menyatakan modul pembelajaran kontekstual berbasis multirepresentasi memiliki keunggulan, yaitu modul dapat digunakan secara mandiri oleh semua siswa karena produk berupa bahan ajar yang disusun dengan langkahlangkah yang bertahap mengikuti 
Shavira., Ertikanto., Suyatna. - Pengaruh Penggunaan Modul Kontekstual...

sintaks pembelajaran kontekstual, serta disajikan dengan banyak representasi sehingga mempermudah siswa dalam memahami materi. Penelitian ini menunjukkan bahwa kelas yang menggunakan modul pembelajaran kontekstual berbasis multirepresentasi memiliki kelebihan ketika pembelajaran dibantu dengan media komputer dan aplikasi phet simulation yang mana pada telah terpandu sesuai sintaks pendekatan kontekstual, sehingga proses pembelajaran semakin bermakna dan siswa dengan mudah memahami materi serta mengaitkan permasalahan dan merepresentasikan ke bentuk lain contohnya seperti hasil perhitungan direpresentasikan ke bentuk tabel dan ke bentuk grafik. Hal ini ternyata berdampak terhadap peningkatan kemampuan berpikir kritis siswa.

Hal ini sejalan juga dengan hasil penelitian Finnajah (2013) yang mengungkapkan bahwa penggunaan modul fisika berbasis multirepresentasi menarik, mudah, bermanfaat, serta efektif sebagai bahan ajar untuk meningkatkan pemahaman konsep dan hasil belajar siswa.

\section{Ucapan Terima Kasih}

Terima kasih untuk keluarga yang selalu memberi semangat, dosen pembimbing dan pembahas untuk kritik dan saran, dan dewan guru di SMA Muhammadiyah 1 Kota Agung karena telah mengizinkan peneliti melakukan penelitian.

\section{KESIMPULAN DAN SARAN}

Berdasarkan hasil penelitian dan pembahasan maka dapat disimpulkan bahwa modul pembelajaran kontekstual berbasis multirepresentasi efektif digunakan untuk meningkatkan kemampuan berpikir kritis siswa dibandingkan bahan ajar konvensional, hal ini didukung dengan perolehan skor rata-rata $\mathrm{N}$ gain kelas eksperimen sebesar 0,71 kategori tinggi. Sedangkan kelas kontrol menggunakan bahan ajar konvensional memperoleh $\mathrm{N}$-gain kelas kontrol 0,60 kategori sedang. Sehingga teruji terdapat pengaruh penggunaan modul kontekstual berbasis multirepresentasi terhadap kemampuan berpikir kritis siswa.

Sebagai tindak lanjut dari penelitian yang telah dilakukan, 
Shavira., Ertikanto., Suyatna. - Pengaruh Penggunaan Modul Kontekstual...

pembelajaran dengan menggunakan modul pembelajaran kontekstual berbasis multirepresentasi dapat dijadikan salah satu alternatif bagi guru di sekolah dalam upaya meningkatkan kemampuan berpikir kritis siswa.

\section{DAFTAR PUSTAKA}

Abdurrahman, Liliasari, Rusli, A., \& Bruce, W. (2011). Impelementasi Pembelajaran Berbasis Multirepresentasi untuk Peningkatan Penguasaan Konsep Fisika Kuantum. Jurnal Cakrawala Pendidikan, 1(1): 3045.

Asfiah, N., Mosik, M., \& Purwantoyo, E. (2013). Pengembangan Modul IPA Terpadu Kontekstual Pada Tema Bunyi. Unnes Science Education Journal, 2(1).

Depdiknas. (2009). Modul/Materi DiklatKTSP. Jakarta.

Fatmala, N. E., Nyeneng, I.D.P., \& Suana, W. (2017). Pengembangan modul pembelajaran kontekstual berbasis multirepresentasi pada materi hukum Newton tentang gravitasi. Jurnal Pendidikan Sains. $1(1): 22-30$.

Finnajah, M. (2016). Pengembangan Modul Fisika SMA Berbasis Multirepresentasi guna Meningkatkan Pemahaman Konsep dan Hasil Belajar. Jurnal Radiasi , 8 (1):22-27.
Irwandani, I. (2014). Multi Representasi sebagai Alternatif Pembelajaran dalam Fisika. Jurnal Ilmiah Pendidikan Fisika AlBiRuNi, 3(1), 39-48.

Khotimah, K., Nyeneng, I.D.P., \& Sesunan, F. (2017). Pengaruh kemampuan berpikir kritis dan respon bahan ajar multirepresentasi terhadap hasil belajar. Jurnal Pendidikan, 5(3) : $1-12$.

Lestari, L., Achmad, A., \& Surbakti, A. (2016). Penerapan Pendekatan Multirepresentasi terhadap Kemampuan Kognitif Siswa pada Materi Sistem Ekskresi. Jurnal Pendidikan Biologi,4(4): 1-12.

Permendikbud nomor 64. (2013). Standar Proses Pendidikan Dasar dan Menengah. Jakarta: Menteri Pendidikan dan Kebudayaan Indonesia..

Pohan, J. E., Atmazaki., \& Agustina. (2014).Pengembangan Modul Berbasis Pendekatan Kontekstual pada Menulis Resensi di Kelas IX SMP 7 Padang Bolak. Jurnal Bahasa, Sastra dan Pembelajaran, 2(2) : 1-11.

Prasetyo, D., Fauzi, A., \& Wiyono, E. (2015). Pengaruh Penggunaan Modul Fisika Berbasis Empat Pilar Pendidikan dengan Spreadsheet Excel pada Materi Gerak Osilasi Terhadap Kemampuan Kognitif Siswa Kelas XI IPA 2 SMA N 1 Surakarta. Jurnal Pendidikan 1(1): 1-6. 